\title{
What Has Changed in the Indications and Outcomes of Cervical Mediastinoscopy for Mediastinal Staging in Non-small Cell Lung Cancer Over the Years?
}

\author{
Yıllar Içerisinde Küçük Hücreli Dıșı Akciğer Kanserinin Mediastinal Evrelemesinde, Servikal \\ Mediastinoskopi Endikasyonu ve Sonuçlarında Neler Değiști?
}

\author{
Volkan Erdogu', Yunus Aksoy', Atilla Pekcolaklar², Muzaffer Metin ${ }^{1}$ \\ ${ }^{1}$ Department of Thoracic Surgery, Yedikule Chest Diseases and Thoracic Surgery Education and Research Hospital, Istanbul; \\ ${ }^{2}$ Thoracic Surgery Department, Bursa City Hospital, Bursa, Turkey
}

\begin{abstract}
Aim: The aim of this study is to observe what has changed in the indications and outcomes of cervical mediastinoscopy (CM) as a result of advancements in the technology and diagnostic methods over the years.
\end{abstract}

Material and Method: A total of 1071 patients, diagnosed with primary non small cell lung cancer (NSCLC) were evaluated retrospectively. CM was indicated in 454 patients (Group 1) out of 610 NSCLC patients between years 2003-2005, whereas 261 patients (Group 2) out of 461 NSCLC patients between years 2017-2019. After exclusions, 195 patients in Group 1 and 194 patients in Group 2 underwent surgery. We compared two groups in terms of CM indications, detection of clinic multiple N2, N3 and single-station cN2 disease with CM, unexpected pathologic (p)N2 ratios and false negativity of CM.

Results: There were 454 of 610 patients (74.4\%) in Group 1 and 261 of 461 patients (56.6\%) in Group 2 were indicated with CM $(p<0.001)$. While 78 patients $(17.2 \%)$ in Group 1 were diagnosed with multiple clinics N2, N3 with CM, 4 patients (1.5\%) in Group 2 $(p<0.001)$. Single-station cN2 was detected in 18 patients $(4 \%)$ in Group 1 and 27 patients (10.3\%) in Group $2(p=0.001)$. While 45 patients (23.1\%) had unexpected pN2 in Group 1, it was found in 18 patients $(9.3 \%)$ in Group $2(p<0.001)$. False negativity found in 17 patients (8.7\%) in Group 1, whereas 8 patients (4.1\%) in Group 2 (0.065). A statistically significant difference was found between the groups in terms of CM indications, diagnosis of clinic multiple N2, cN3, single-station cN2 and detection of unexpected pN2.

Conclusion: Over the years, as a result of advancements in technology and minimally invasive techniques, cervical mediastinoscopy indications, clinical multiple N2, cN3 disease detection with CM, unexpected $p N 2$ detection in surgery and false negativity ratios of CM have decreased.

Key words: cervical mediastinoscopy; false negativity; mediastinal staging; unexpected $\mathrm{N} 2$

\section{ÖZET}

Amaç: Bu çalıșmanın amacı, yıllar içinde teknoloji ve tanı yöntemlerinde yașanan gelișmeler sonucunda servikal mediastinoskopi (MK) endikasyon ve sonuçlarında nelerin değiștiğini gözlemlemektir.

Materyal ve Metot: Primer küçük hücreli dıșı akciğer kanseri (KHDAK) tanısı alan toplam 1071 hasta retrospektif olarak değerlendirildi. MK endikasyonu, 2003-2005 yılları arasında 610 KHDAK hastasının 454'üne (Grup 1), 2017-2019 yılları arasında 461 KHDAK hastasından 261 'ine (Grup 2) kondu. Çalıșmadan çıkarılan hastalar sonrasında, Grup 1'de 195 hasta ve Grup 2'de 194 hasta ameliyat edildi. MK endikasyonları, MK ile klinik multipl N2, N3, tek istasyon klinik N2 tespiti, beklenmedik patolojik (p)N2 oranları ve MK'nin yanlıș negatifliği açısından iki grup karșılaștırıldı.

Bulgular: Grup 1'de 610 hastanın 454'üne (\%74,4), Grup 2'deki 461 hastanın 261 'ine $(\% 56,6)$ MK endikasyonu kondu $(p<0,001)$. Grup 1'de 78 hastada $(\% 17,2)$ MK ile multipl klinik N2 ve N3 tanısI konulurken, Grup 2'de 4 hastaya $(\% 1,5)$ bu tanı kondu $(p<0,001)$. Grup 1'de 18 hastada (\%4), Grup 2'de 27 hastada (\%10,3) klinik tek istasyon N2 tespit edildi $(p=0,001)$. Grup 1'de 45 hastada $(\% 23,1)$ beklenmeyen pN2 bulunurken, Grup 2'de 18 hastada $(\% 9,3)$ bulundu $(p<0,001)$. Grup 1'de 17 hastada $(\% 8,7)$ yalancı negatiflik bulunurken, Grup 2'de ise 8 hastada $(\% 4,1)$ yanlıș negatiflik bulundu (0,065). MK endikasyonları, multipl N2, N3, tek istasyon klinik N2 tanısı ve beklenmedik pN2 saptanması açısından gruplar arasında istatistiksel olarak anlamlı fark bulundu.

Sonuç: Yıllar içinde, teknolojideki ve minimal invaziv tekniklerdeki gelișmeler sonucunda, servikal mediastinoskopi endikasyonları, MK ile klinik multipl N2, N3 hastalık tespiti, cerrahide beklenmedik pN2 tespiti ve MK'nin yanlıș negatiflik oranları azalmıștır.

Anahtar kelimeler: servikal mediastinoskopi; yanlıs negatiflik; mediastinal evreleme; beklenmeyen N2

iletișim/Contact: Volkan Erdoğu, Department of Thoracic Surgery, Yedikule Chest Diseases and Thoracic Surgery Education and Research Hospital, Istanbul, Turkey • Tel: 05052414436 • E-mail: verdogu@gmail.com • Geliș/Received: 30.04.2020 • Kabul/Accepted: 19.09 .2020

ORCID: Volkan Erdoğu, 0000-0002-7524-0151 • Yunus Aksoy, 0000-0003-4966-2809 • Atilla Pekçolaklar, 0000-0002-5880-7822 • Muzaffer Metin, 0000-0003-0804-2654 


\section{Introduction}

The current staging system in lung cancer includes tumor size $(\mathrm{T})$, regional lymph node metastasis $(\mathrm{N})$, and distant metastasis $(\mathrm{M})$. Treatment of lung cancer is determined according to tumor stages ${ }^{1}$. In the absence of distant metastasis, one of the most important prognostic factors is lymph node metastasis. Radiological methods, minimally invasive and invasive techniques are used for preoperative mediastinal staging. Ipsilateral multiple mediastinal lymph node metastases (multiple N2) and contralateral mediastinal lymph node metastasis (N3) do not benefit from surgery in non-small cell lung cancer (NSCLC) patients ${ }^{2,3}$. Therefore, preoperative evaluation of mediastinal lymph nodes is crucial and prevents unnecessary thoracotomies. With the advancements of technology, positron emission tomography-computed tomography (PET-CT) has started to take an important place in the non-invasive staging of mediastinal lymph nodes ${ }^{4}$. Cervical staging mediastinoscopy (CM) is an invasive gold standard method for mediastinal staging5. Recently, endobronchial ultrasoundguided transbronchial needle aspiration (EBUSTBNA) and transesophageal ultrasound-guided fine needle aspiration (EUS-FNA) have become the first choice for mediastinal staging in many centers due to their minimally invasive nature's advantages ${ }^{6}$. The indications for CM appear to be decreasing with the introduction of minimally invasive and non-invasive techniques in medaistinal staging ${ }^{7}$. In addition, with the use of minimally invasive techniques, preoperative staging algorithms have begun to change in recent guidelines ${ }^{8}$. However, the effects of recent technological advancements regarding mediastinal staging on CM outcomes and indications are unknown.

The purpose of this study was to evaluate whether the $\mathrm{CM}$ indications and the outcomes have differed with the advancement of technology and new mediastinal staging algorithms over the years in NSCLC patients.

\section{Materials and Methods}

Out of 610 NSCLC patients, 454 patients (Group 1) had indications for CM between the years 20032005 and out of 461 patients, 261 patients (Group 2) had indications for CM between 2017-2019. These patients were evaluated retrospectively. In group 1, indications for $\mathrm{CM}$ were determined by contrast computed tomography (CT). CM was performed in cases with mediastinal lymph nodes larger than 1 $\mathrm{cm}$ in CT evaluation. In Group 2, mediastinal staging was performed as suggested by current guidelines of European Society of Thoracic Surgeons (ESTS) ${ }^{9}$. According to the latest algorithm recommendations, EBUS/EUS should be considered as the first choice in cases with mediastinal lymph nodes larger than $1 \mathrm{~cm}$ on CT with positive PET-CT findings since EBUS is minimally invasive and has a similar sensitivity to CM. If clinically No ( $\mathrm{cN}$ ) disease is detected with EBUS, the result should be confirmed with video-assisted mediastinoscopic lymphadenectomy (VAMLA) or CM. Even in the absence of radiological evidence, invasive mediastinal staging methods are recommended in central tumors with suspected hilar lymph node positivity (N1), adenocarcinoma histology and tumors larger than $3 \mathrm{~cm}$. We used this algorithm for mediastinal staging in Group 2.

The technique of CM involved a standard cervical incision where the layers were passed, the pretracheal fascia was dissected and the mediastinoscope was inserted. The paratracheal area was reached with blunt dissections towards the carina, and the upper $(2 \mathrm{R}$ and $2 \mathrm{~L})$ and lower paratracheal lymph nodes (4R and $4 \mathrm{~L}$ ) and subcarinal lymph nodes (7) were routinely explored. All stations were examined and visible lymph nodes were sampled. ESTS recommendations were taken into consideration for the number of lymph node stations sampled in $\mathrm{CM}^{10}$, They recommend for an appropriate mediastinal staging with $\mathrm{CM}$, at least one sample from the lower paratracheal station and one from the subcarinal station and, if present, a sample from the upper paratracheal lymph node (s). The sampled lymph nodes were staged according to The American Joint Committee on Cancer (AJCC) staging system, as recommended by Mountain ${ }^{11}$. While patients with single-station cN2 disease detected in CM were referred to neoadjuvant therapy, patients with multiple $\mathrm{N} 2$ and $\mathrm{cN} 3$ diseases were referred for adjuvant therapy to the oncology clinics. Regarding patients with cN0 disease, those with resectable tumors and fit for thoracic surgery were operated on. During the operation, we perform systematic mediastinal lymph node dissection for mediastinal staging. All mediastinal lymph node stations from 5 to 9 and hilar lymph nodes (stations 10 and 11) were dissected en bloc, not sampled. Recently we perform lobe specific lymph node dissection in early stage NSCLC as suggested by ESTS ${ }^{12}$. Therefore, at least 3 mediastinal lymph nodes were dissected in the drainage path of the lobe 
with the requirement of one lymph node being from the subcarinal (number 7) station. Resected materials and lymph nodes were assessed histopathologically by the experienced pathologists. False negativity was accepted as the detection of tumor metastasis in the pathological examination in at least one of the mediastinal lymph node stations (2R, 2L, 4R, 4L, 7) that can be reached by CM. Since the aorticopulmonary and paraaortic (station 5-6) stations can be reached with extended mediastinoscopy, the metastases of these regions were not considered to be false negatives of CM. Also paraesophageal and inferior ligament lymph node (station 8-9) metastases were not considered to be false negatives of $\mathrm{CM}$ since $\mathrm{CM}$ can not reach those stations also. Unexpected N2 was defined as tumor involvement in any mediastinal lymph node (Station 2-4-5-6-7-8-9) on pathological examination, despite finding cN0 with $\mathrm{CM}$.

\section{Inclusion and Exclusion Criteria}

A total of 1071 patients diagnosed NSCLC in the present study (Group 1; n=610, Group 2; n=461). In Group 1, 454 (74.4\%) patients had indications for CM whereas 261 (56.6\%) patients had indications for CM in Group 2. Since neoadjuvant treatment positively affected false negativity and unexpected N2 ratios, these patients were excluded from the present study [(Group 1; 60 patients (Although 42 of them reported $\mathrm{cN} 0$, for a subject of a different study they underwent neoadjuvant treatment, 18 patients due to $\mathrm{cN} 2$, Group 2; 27 patients due to $\mathrm{cN} 2$ ). Patients who refused operation or those operated in some other hospital were excluded
(Group 1; n=24, Group 2; n=3). As a result of major complications/exitus during CM (major hemorrhage causing the procedure to end and/or requiring a thoracotomy or sternotomy) patients who could not have effective mediastinal lymph node sampling were excluded (Group 1; 8 major complications, 1 perioperative exitus, Group 2; 1 major complication). During surgery 33 patients in Group 1, considered inoperable due to tumor invasion into the surrounding tissues and remained in the exploration stage, were excluded. There were no patients who remained in the exploration stage in Group 2. Patients with insufficient intraoperative lymph node dissection (have not sampled at least 3 $\mathrm{N} 2$ stations in the drainage path of the lobe) were also excluded since the false negativity of CM could not be evaluated (Group 1; $\mathrm{n}=55$, Group 2; $\mathrm{n}=32$ ). A total of 244 patients [(Group 1; $n=181$ (74.2\%), Group $2 ; n=63(25.8 \%)]$ were excluded and 471 patients [(Group 1; n=273 (57.9\%), Group 2; n=198 (42.1\%)] were included to the study (Table 1 ).

The study was approved by our Institutional Review Board and was conducted in accordance with the principles of the Declaration of Helsinki.

\section{Statistical Analysis}

The demographic characteristics of the patients and the collected data were entered from $\mathrm{IBM}^{\circ} \mathrm{SPSS}^{\circ}$ (the Statistical Package for the Social Sciences) Statistics entered into version 25. Variables were characterized by using average, maximum and minimum values. Percentage values were used for qualitative variables. Normal distributions were reported as mean \pm

Table 1. Exclusion criteria

\begin{tabular}{lccc}
\hline Exclusion details & Group 1, N (\%) & Group 2, N (\%) & Total, N (\%) \\
\hline Total non-small cell lung cancer patients & $610(56.9 \%)$ & $461(43.1 \%)$ & 1071 \\
CM indicated patients & $454(74.4 \%)$ & $261(56.6 \%)$ & $715(66.7 \%)$ \\
Neoadjuvant treatment - subject of a different study & $42(9.2 \%)$ & $0(0 \%)$ & $42(5.8 \%)$ \\
Neoadjuvant treatment because of cN2 & $18(3.9 \%)$ & $27(10.3 \%)$ & $45(6.3 \%)$ \\
Operated in some other hospital or refused surgical treatment & $24(5.3 \%)$ & $3(1.1 \%)$ & $27(3.7 \%)$ \\
Major complications/exitus during CM & $9(1.2 \%)$ & $1(0.4 \%)$ & $10(1.4 \%)$ \\
Remained in exploration stage during thoracotomy & $33(7.2 \%)$ & $0(0 \%)$ & $33(4.6 \%)$ \\
Intraoperative insufficient lymph node sampling & $55(12.1 \%)$ & $32(12.2 \%)$ & $87(12.1 \%)$ \\
Total excluded patients & $181(39.8 \%)$ & $63(24.1 \%)$ & $244(34.1 \%)$ \\
Total included to the study & $273(60.2 \%)$ & $198(75.9 \%)$ & $471(65.9 \%)$ \\
\hline
\end{tabular}

CM, cervical mediastinoscopy; cN2, clinic N2; N, number. 
SD and Student's t-test was used for comparison of groups. Pearson's chi-square was used for the analysis of qualitative variables, Fisher's exact test was used if the group was small $(<5)$. Nonparametric continuous variables were recorded as median and ranged distribution and they were compared by using MannWhitney $\mathrm{U}$ tests. $\mathrm{p}<0.05$ was accepted as statistically significant.

\section{Results}

The mean age of the patients who underwent CM was $58.8 \pm 7.2$ (range $28-80$ years). The mean age in Group 1 was $56.4 \pm 7.5$ (range 28-77 years), whereas it was $61.2 \pm 7.3$ (range $40-80$ years) in Group 2. The majority of the patients were men $(n=681,95.2 \%)$. In Group 1, there were 441 male patients (97.1\%), whereas 240 patients (91.9\%) were male in Group 2. There was no significant difference between the groups in terms of age and gender (Table 2). There were a total of 1071 patients diagnosed with NSCLC in both groups. Four hundred and fifty-four (74.4\%) of 610 NSCLC cases in Group 1 and 261 (56.6\%) of 461 NSCLC cases in Group 2 had indications for CM. CM indication was found significantly higher in Group 1 ( $\mathrm{p}<0.001)$. Major complications developed in 9 patients $(2 \%)$ in Group 1, while in one patient $(0.4 \%)$ in Group 2. There were no significant differences in terms of major complications between the groups $(p=0.103)$. Eighteen patients were detected as single-station cN2 (4\%) in Group 1, whereas 27 patients (10.3\%) in Group 2. This difference was found statically significant $(\mathrm{p}=0.001)$. Clinic multiple $\mathrm{N} 2$ and $\mathrm{cN} 3$ were found in 78 patients (17.2\%) in Group 1 while in only 4 patients (1.5\%) in Group 2. This difference between groups was found to be significant $(\mathrm{p}<0.001)$. After referring $\mathrm{cN} 2, \mathrm{cN} 3$ patients to the oncology clinics, $389 \mathrm{cN} 0$ patients remained and underwent surgery (Group 1; $\mathrm{n}=195,42.9 \%$, Group 2; n=194, 74.3\%).

Despite current diagnostic and interventional methods, unexpected pN2 was detected in 45 patients (23.1\%) in the postoperative pathology reports in Group 1, whereas in 18 patients (9.3\%) in Group 2. The difference between groups was significant in regards to unexpected $\mathrm{pN} 2$ ratios $(\mathrm{p}<0.001)$. False negative $\mathrm{pN} 2$ was detected in 17 patients $(8.7 \%)$ in Group 1 and 8 patients (4.1\%) in Group 2. There was a trend toward significance differences between groups in terms of false negativity $(p=0.065)$. The most frequent false negativity was detected at station 7 in both groups. False negativity of station 7 was detected in $13(6.6 \%)$ patients in Group 1, and 6 (3\%) patients in Group 2. False negativity of $4 \mathrm{R}$ was detected in 4 patients $(2 \%)$ in Group 1 , whereas in 2 patients (1\%) in Group 2. There was no statistically significant difference between the groups in terms of false negativity for stations 7 and $4 \mathrm{R}$ (Station 7; $\mathrm{p}=0.102$, Station 4R; $\mathrm{p}=0.685$ ). Demographic and pathological features of the patients are all listed in Table 2.

Table 2. Demographic and pathological features of the patients

\begin{tabular}{|c|c|c|c|c|}
\hline Variables & Total, $(n=715)$ & Group $1,(n=454)$ & Group 2, $(n=261)$ & $\mathrm{p}$ value \\
\hline \multicolumn{5}{|l|}{ Gender, $\mathrm{n}(\%)$} \\
\hline Male & $681(95.2 \%)$ & $441(97.1 \%)$ & $240(91.9 \%)$ & 1.000 \\
\hline Female & $34(4.8 \%)$ & $13(2.9 \%)$ & $21(8.1 \%)$ & \\
\hline Age, years $\pm S D$ & $58.8 \pm 7.2$ & $56.4 \pm 7.5$ & $61.2 \pm 7.3$ & 0.457 \\
\hline Indication of $\mathrm{CM}, \mathrm{n}(\%)$ & $715 / 1071(66.8 \%)$ & $454 / 610(74.4 \%)$ & $261 / 461(56.6 \%)$ & $<0.001$ \\
\hline Major complications, $\mathrm{n}(\%)$ & $10(1.4 \%)$ & $9(2 \%)$ & $1(0.4 \%)$ & 0.103 \\
\hline Neoadjuvant treatment because of cN2, $\mathrm{n}(\%)$ & $45(6.3 \%)$ & $18(4 \%)$ & $27(10.3 \%)$ & 0.001 \\
\hline Clinic multiple N2-N3, n (\%) & $82(11.4 \%)$ & $78(17.2 \%)$ & $4(1.5 \%)$ & $<0.001$ \\
\hline Patients underwent resection*, n (\%) & 389 (54.4\%) & 195 (42.9\%) & $194(74.3 \%)$ & \\
\hline - Unexpected pN2, n (\%) & $63(16.2 \%)$ & $45(23.1 \%)$ & $18(9.3 \%)$ & $<0.001$ \\
\hline - False negative, $\mathrm{n}(\%)$ & $25(6.4 \%)$ & $17(8.7 \%)$ & $8(4.1 \%)$ & 0.065 \\
\hline - Station $7, \mathrm{n}(\%)$ & $19(4.9 \%)$ & $13(6.6 \%)$ & $6(3 \%)$ & 0.102 \\
\hline - Station 4R, n (\%) & $6(1.5 \%)$ & $4(2 \%)$ & $2(1 \%)$ & 0.685 \\
\hline
\end{tabular}

CM, cervical mediastinoscopy; n, number; N, node; cN2, clinic N2; N2-N3, clinic N2, N3; pN2, pathological N2; SD, standard deviation.

*Anatomic lung resection which was at least a lobectomy and mediastinal lymph node dissection. 
According to the findings of the present study, the sensitivity, specificity, negative predictive value (NPV) of CM in Group 1 was found to be $84.8 \%, 100 \%$ and $91.2 \%$ respectively, whereas it was $60 \%, 100 \%$ and $96.2 \%$ in Group 2 (Table 3).

\section{Discussion}

The clinical stage in lung cancer is not always the same as the pathological stage. Therefore, appropriate mediastinal staging is very important in determining the treatment strategy to be selected. For this purpose, radiological imaging methods as non-invasive procedures, fiberoptic bronchoscopy, EBUS/EUS as minimally invasive, and CM as invasive techniques are used by physicians. Although CM is a gold standard technique for mediastinal staging, indications of CM appear to be decreasing with the advancement of imaging methods and minimally invasive techniques ${ }^{13}$.

Since the first application of CM in the 1950s, its use gradually increased and it became available in most thoracic surgery clinics in the $1970 \mathrm{~s}^{14,15}$. According to Martin et al. ${ }^{16}$, the indications for CM between 1986 and 1992 was $16 \%$ and between 1993 and 2001 this rate reached $32 \%$. As seen in the literature, after CM became popular in the mediastinal staging of lung cancer, referral to CM appears to increase in the early years. In the present study, it is remarkable that Group 1's CM indications are excessive (Group 1, CM indication 74.4\%). CM has been performed in our clinic since the 1990 s. The thoracic surgery team is highly experienced in this regard. We think the reason for the excess ratio is because we adhere firmly to the indications of CM. In a multicenter retrospective study conducted in the USA, 9749 patients from 163 centers were examined, and in 2006, the number of patients requiring $\mathrm{CM}$ was found to be $14.6 \%$ and it decreased to $11.4 \%$ in 2010 . In conclusion they stated, with advances in minimally invasive procedures and imaging, mediastinoscopy usage has declined significantly ${ }^{17}$. Similar to the literature findings, there was a significant decrease in CM indication in Group 2, as EBUS was successfully applied in many centers.

Table 3. CM sensitivity, specificity, NPV

\begin{tabular}{cccc}
\hline Groups & Sensitivity & Specificity & (NPV) \\
\hline 1 & $84.8 \%$ & $100 \%$ & $91.2 \%$ \\
2 & $60 \%$ & $100 \%$ & $96.2 \%$ \\
\hline
\end{tabular}

CM, cervical mediastinoscopy; NPV, negative predictive value
The success of mediastinal staging has significantly increased with the introduction of PET-CT, at $75 \%$ positive predictive value (PPV) and 99\% negative predictive value (NPV) ${ }^{18}$. PET-CT has begun to be actively used in public hospitals in Turkey since the second half of $2004^{19}$. However, because PET-CT could not be used in our patient population before 2005, PET-CT imaging was not performed in Group 1 patients. CM maintains its importance in mediastinal staging with its $76-85 \%$ sensitivity, $100 \%$ specificity, $82-92 \%$ negative predictive value (NPV) rates and very low rates in morbidity $(1.07 \%)$ and mortality $(0.05 \%)^{20}$. While the NPV rates of CM in the literature were $81 \%$ in the early 2000s, rates have increased significantly after 2010 and reached $95 \%^{21,22}$. NPV rates of CM have increased in the present study over the years in accordance with the literature.

EBUS has similar diagnostic staging values as $\mathrm{CM}$ with $80 \%$ sensitivity, $100 \%$ specificity and $90.5 \% \mathrm{NPV}^{23}$. Recent guidelines have reported combined EBUS/ EUS should be used as a first line mediastinal staging method as it does not require general anesthesia, it is minimally invasive and can access the posterior carinal, inferior mediastinal and hilar regions ${ }^{23}$. Although PET-CT and EBUS/EUS have been included in the 2006 staging guidelines of ESTS, EBUS/EUS has begun to be used in public hospitals after 2008 in Turkey ${ }^{24}$. Therefore, EBUS/EUS procedure could not be used in Group 1 patients for mediastinal staging.

There is a significant difference between Group 1 and Group 2 in terms of indications for CM over the years. This is probably due to the introduction of PET-CT and EBUS/EUS in mediastinal staging. It seems that, as a result of the non-invasive detection of clinical multiple $\mathrm{N} 2$ and $\mathrm{N} 3$ patients, $\mathrm{CM}$ was no longer required in Group 2 patients. This is probably the reason why unexpected N2 patients were significantly reduced in Group 2, as they were diagnosed preoperatively. Despite the detection of $\mathrm{cNO}$ by non-invasive and invasive staging techniques, the detection of unexpected $\mathrm{pN} 2$ during thoracotomy has been reported to be between $15-32 \%$ in literature ${ }^{25}$. Unexpected $\mathrm{pN} 2$ patients in Group 2 were below the literature results with $9.3 \%$. This low rate is likely due to the successful use of preoperative invasive and minimally invasive mediastinal staging techniques, as seen from the increased detection of single-station cN2 diseases in Group 2. Recent studies stated that patient selection for CM with guided PET-CT findings had better results than routinely performed $\mathrm{CM}^{26}$. We think that 
the detection of $\mathrm{cN} 2$ patients with $\mathrm{CM}$ in Group 2 has increased due to the selection of more specific patient groups that are candidates for $\mathrm{cN} 2$ with the PET$\mathrm{CT}$ guideline. In addition, the detection of more $\mathrm{cN} 2$ patients with CM may be explained by the increased skills of surgeons over the years, as evidenced by the decreases of major complications. Although there was no significant difference between the 2 groups in terms of false negativity, this difference exhibited a trend toward significance. We think that the detection of more single-station $\mathrm{cN} 2$ patients with $\mathrm{CM}$ led to a decrease in false negativity in Group 2. Lemaire A et al. ${ }^{27}$ observed a $5.5 \%$ false negative ratio similar to our findings in Group 2 (4.1\%).

In the present study, the false negativity ratio in Group 1 was found to be $8.7 \%$. Luke WP et al. ${ }^{28}$ reported their false negative ratios as $8.8 \%$ and years later in another study, Hammoud ZT et al. ${ }^{29}$ reported their false negative ratios as $8 \%$. These results were similar to our results. Consistent with the literature, the most common false negativity in both groups occurred in the subcarinal lymph node station and less frequently in the right lower paratracheal station ${ }^{30}$. The subcarinal region is a large area and $\mathrm{CM}$ can not reach every part hence $\mathrm{CM}$ is unable to sample posterior carinal regions. In addition, this area is surrounded by many important vessels, and damage to them can cause life-threatening bleeding. This risk may prevent adequate sampling ${ }^{31}$. All this may explain the high false negative ratios of the subcarinal lymph node.

The present study has some limitations. In both groups, we did not specify our clinical stages retrospectively before CM. Although the reduction in CM rates and $\mathrm{pN} 2$ detection rates in surgery was explained by the advancement in PET-CT and other minimally invasive staging methods, we did not include our clinic's PETCT, EBUS/EUS sensitivity and specitivity rates in the present study. Despite all this, we believe that this historical cross-sectional study well demonstrated changes in CM over the years with a large patient series.

In conclusion, cervical mediastinoscopy is still the gold standard of mediastinal staging with high sensitivity, specificity and negative predictive values even though there is a decrease in its indications over the years due to the advancement of technology and minimally invasive techniques. In the last 12 years, detection of clinic multiple $\mathrm{N} 2$ and $\mathrm{cN} 3$ disease with $\mathrm{CM}$, unexpected $\mathrm{pN} 2$ detection in surgery and false negative rates of CM have decreased.

\section{Declaration of Conflicting Interests}

The authors declared no conflicts of interest with respect to the authorship and/or publication of this article.

\section{Funding}

The authors received no financial support for the research and/or authorship of this article.

\section{References}

1. Goldstraw P, Crowley JJ, Chansky K, Dorothy JG, Patti AG, Porta RR, et al. The IASLC Lung Cancer Staging Project: proposals for the revision of the TNM stage groupings in the forthcoming (seventh) edition of the TNM classification of malignant tumors. J Thorac Oncol 2007;2:706-714.

2. R. J. Cerfolio, L. Maniscalco, and A. S. Bryant, "The treatment of patients with stage IIIA non-small cell lung cancer from N2 disease: who returns to the surgical arena and who survives, " Ann. Thorac. Surg 2008. Vol 86, no 3:912-920.

3. Albain KS, Swann RS, Rusch VW, et al. Radiotherapy plus stage III chemotherapy for non-small cell lung cancer with or without surgical resection: a phase III randomized controlled trial. Lancet 2009;374:379-386.

4. Caitlin AS, Vivek V, Carl MP, Abigail TB, Melissa AF, Anil $\mathrm{V}$, et al. Outcomes of invasive mediastinal nodal staging versus positron emission tomography staging alone for early-stage nonsmall cell lung cancer treated with stereotactic body radiation. Lung Cancer 2018;117:53-59.

5. Muzaffer M, Necati C, Songül B, Abdulaziz K, Alper C, Okan $S$, et al. Does the efficiency of mediastinoscopy for mediastinal staging of lung cancer increase in time? Thorac Cardiovasc Surg 2015;23:499-506.

6. Zhang R, Mietchen C, Krüger M, Bettina W, Heiko G, Sabine D, et al. Endobronchial ultrasound guided fine needle aspiration versus transcervical mediastinoscopy in nodal staging of non-small cell lung cancer: a prospective comparison study. J Cardiothorac Surg 2012;7-51.

7. Ettinger DS, Wood DE, Akerley W, Bazhenova LA, Borghaei $\mathrm{H}$, Camidge DR, et al. NCCN guidelines insights: non-small cell lung cancer, version 4, 2016. J Natl compr cancer netw 2016;14:255-264.

8. De Leyn P, Dooms C, Kuzdzal J, Lardinois D, Passlick B, Rami-Porta R, et al. Revised ESTS guidelines for preoperative mediastinal lymph node staging for non-small-cell lung cancer. Eur J Cardiothorac Surg 2014; 45:787-798.

9. Postmus PE, Kerr KM, Oudkerk M, Senan S, Waller DA, Vansteenkiste J, et al. ESMO Guidelines Committee. Early and locally advanced non-small-cell lung cancer (NSCLC): ESMO Clinical Practice Guidelines for diagnosis, treatment and followup. Ann Oncol 2017;28:410-421. 
10. Silvestri GA, Gonzalez AV, Jantz MA, Margolis ML, Gould MK, Tanoue LT, et al. Methods for staging non-small cell lung cancer: diagnosis and management of lung cancer, 3rd ed: American College of Chest Physicians evidence-based clinical practice guidelines. Chester 2013;143:50-52.

11. Rusch VW, Asamura H, Watanabe H, Giroux DJ, Porta RR, Goldstraw P. “The IASLC lung cancer staging project: a proposal for a new international lymph node map in the forthcoming seventh edition of the TNM classification for lung cancer, "J. Thorac. Oncol 2009;4:568-577.

12. Lardinois D1, De Leyn P, Van Schil P, Porta RR, Waller D, Passlick B et al. . ESTS guidelines for intraoperative lymph node staging in non-small cell lung cancer. Eur J Cardiothorac Surg 2006;30:787-792.

13. Sayar A, Citak N, Metin M, Turna A, Pekçolaklar A, Kök A, et al. Comparison of video-assisted mediastinoscopy and videoassisted mediastinoscopic lymphadenectomy for lung cancer. Gen Thorac Cardiovasc Surg 2011;59:793-798.

14. Carlens E, Mediastinoscopy: a method for inspection and tissue biopsy in the superior mediastinum. Dis Chest 1959;36:343352.

15. Sarin CL, Nohl-Oser HC Mediastinoscopy: a clinical evaluation of 400 consecutive cases. Thorax 1969;24:585-588.

16. Martin LW, Correa AM, Hofstetter W, Hong WK, Komaki R, Putnam JB Jr, et al. The evolution of treatment outcomes for resected stage IIIA non-small cell lung cancer over 16 years at a single institution. J Thorac Cardiovasc Surg 2005;130:16011610.

17. Vyas KS, Davenport DL, Ferraris VA, Saha SP. Mediastinoscopy: Trends and Practice Patterns in the United States South Med. South Med J 2013;10:539-544.

18. Arvind K, Roman D, Umashankkar K, Rakesh K, Gopi CK, et all. Evaluation of mediastinal lymph nodes using $18 \mathrm{~F}-\mathrm{FDG}$ PET-CT scan and its histopathologic correlation Ann Thorac Med 201;6:11-16.

19. Hikmet B. Pozitron emissyon tomografi (pet) history of positron emission tomography Bulletin of Thoracic Surgery 2015;6:130-145.

20. İlker I, Çağatay T, Salih ZK, Altan K, The role of standard and extended cervical mediastinoscopy in the staging of non-small cell lung cancer patients. Thorac Cardiovasc Surg 2011;19:405409.

21. Lardinois D, Schallberger A, Betticher D, Ris HB. Postinduction video-mediastinoscopy is as accurate and safe as video-mediastinoscopy in patients without pretreatment for potentially operable non-small cell lung cancer, Ann Thorac Surg, 2003;75:1102-1106.
22. Cho JH, Kim J, Kim K, Choi YS, Kim HK, Shim YM. A comparative analysis of video-assisted mediastinoscopy and conventional mediastinoscopy, Ann Thorac Surg, 2011;92:1007-1011.

23. Yasufuku K, Pierre A, Darling G, Marc Perrot, Thomas W, Michael J, et al. A prospective controlled trial of endobronchial ultrasound-guided transbronchial needle aspiration compared with mediastinoscopy for mediastinal lymph node staging of lung cancer. J Thorac Cardiovasc Surg 2011;142:1393-1400.

24. Navani N, Fisher DJ, Tierney JF, Stephens RJ, Burdett S, NSCLC Meta-analysis Collaborative Group Lung cancer staging: accuracy is critical. The Accuracy of Clinical Staging of Stage I-IIIa Non-Small Cell Lung Cancer: An Analysis Based on Individual Participant Data. Chest 2019;155:502-509.

25. Tachi R, Hattori A, Matsunaga T, Takamochi K, Oh S, Suzuki K The impact on the prognosis of unsuspected N2 disease in nonsmall-cell lung cancer: indications for thorough mediastinal staging in the modern eraSurg Today 2017;47:20-26.

26. Metin M, Citak N, Sayar A, Pekcolaklar A, Melek H, Kök A, et al. The role of extended cervical mediastinoscopy in staging of non-small cell lung cancer of the left lung and a comparison with integrated positron emission tomography and computed tomography: does integrated positron emission tomography and computed tomography reduce the need for invasive procedures? J Thorac Oncol 2011;6:1713-1719.

27. Lemaire A, Nikolic I, Petersen T, Haney JC, Toloza EM, Harpole DH Jr, et al. Nine-year single center experience with cervical mediastinoscopy: complications and false negative rate. Ann Thorac Surg 2006;82:1185-1189.

28. Luke WP, Pearson FG, Todd TR, Patterson GA, Cooper JD. Prospective evaluation of mediastinoscopy for assessment of carcinoma of the lung. J Thorac Cardiovasc Surg 1986;91:5356.

29. Hammoud ZT, Anderson RC, Meyers BF, Guthrie TJ, Roper $\mathrm{CL}$, Cooper JD, et al. The current role of mediastinoscopy in the evaluation of thoracic disease. J Thorac Cardiovasc Surg 1999;118:894-899.

30. Anraku M, Miyata R, Compeau C, Shargall Y. Videoassisted mediastinoscopy compared with conventional mediastinoscopy: are we doing better? Ann Thorac Surg 2010;89:1577-41581.

31. Citak N, Buyukkale S, Kok A, Celikten A, Metin M, Sayar A, et al. Does video-assisted mediastinoscopy offer lower falsenegative rates for subcarinal lymph nodes compared with standard cervical mediastinoscopy? Thorac Cardiovasc Surg 2014;62:624-630. 